\title{
Evaluation of Watershed Scale Changes in Groundwater and Soil Moisture Storage with the application of GRACE Satellite Imagery data
}

\author{
Anteneh Z. Abiy ${ }^{1}$, Assefa M. Melesse
}

Geospatial Applications and Hydrological Modeling Lab, Department of Earth and Environment, Florida International University, Miami, USA.

\begin{abstract}
As a hidden resource, our understanding and knowledge on the distribution of groundwater and its quantity is limited. In areas where such data is scarce, geo-observatory products such as the Gravity Recovery and Climate Experiment (GRACE) can provide an accurate estimate of changes in total terrestrial water storage at a coarser, regional resolution. However, in the Lake Tana basin, Ethiopia, groundwater is stored in localized aquifers, and its flow is controlled by physical variables (local geology, soil cover, slope, elevation difference, topographic index and drainage density) and climate (rainfall). The objective of this study is to utilize GRACE (CSR RL05) for the evaluation of spatial and temporal changes of soil moisture and groundwater storage at watershed scale. A geographic information system (GIS) based multi-layer analysis of the physical variables is implemented to delineate aquifer potential zones. The aquifer potential zone of the basin is combined with the GRACE (CSR RL05) based change in total terrestrial water storage data. Accordingly, the very high and high potential aquifer zone classes demarcate hot spots of high groundwater storage fluctuations recorded by the satellite data. The change in storage fluctuation of the 11-year monthly data, from 2003 to 2013, reveals that the total terrestrial water storage of the basin has declined by $18.37 \mathrm{~cm}$. This is equivalent to the loss of 2.21 BCM of water within 11 years. Groundwater and soil moisture gains are a response of recharge, hence it is highly recommended to promote groundwater recharge, soil moisture harvesting, and sustainable use. On the other hand, the study highlights the possibility of application of the regional GRACE (CSR RL05) product for watershed-scale evaluations.
\end{abstract}

\footnotetext{
${ }^{1}$ Corresponding author: ECS-168, Geospatial Applications and Hydrological Modeling Lab, Department of Earth and Environment, Florida International University, 11200 SW 8th Street. Miami, FL 33199, USA. E-mail: aabiy001@fiu.edu
} 
27 Key Words: Gravity Recovery and Climate Experiment (GRACE), Groundwater storage, Soil 28 moisture, Tana basin, Blue Nile River 


\section{Introduction}

In the face of increasing demand for water use (Wade et al., 2010), decision making and sustainable water resources management demands tangible information about the quantity, quality and spatiotemporal distribution of water resources. Groundwater accounts for most of the freshwater resources in many terrestrial river basins (Wade et al., 2010; Famiglietti and Rodell, 2013). Although the potential is not yet well defined in the Tana basin, groundwater accounts for most of the water supply in the area (Abiy et al., 2015; Kebede et al., 2006). However, due to the increasing demand for domestic, agricultural and industrial use, groundwater is overexploited, leading to the decline of wells productivity and stream discharge (Nigate et al., 2016; Abiy et al., 2015; Enku et al., 2014). Sound knowledge of the aquifer's flow and storage changes allow dependable water resources management and related decision making. Therefore, reliable information derived from analytical tools and use of emerging technology options, such as remote sensing products, can help in sustainable management and equitable allocation.

Recently, the emergence of the Gravity Recovery and Climate Experiment (GRACE) satellite has brought a new dimension to water resources study, regionally (Rodell and Famiglietti, 2001; Famiglietti and Rodell, 2013). After processing at different levels, the Center for Space Research at the University of Texas, Austin, presents the GRACE (CSR RL05) data which indicates monthly anomalies of total terrestrial water storage (Ward, 2004; Long et al., 2013). This data set provides the net change in total territorial water storage ( $\Delta$ TWS ) having calculated the balance between gain and loss terms, such as evapotranspiration (ET). Therefore, $\Delta$ TWS represents the sum of the change in storage from aquifers, soil moisture, surface water reservoirs (lakes, ponds) and snow water storage (Ward, 2004; Castle et al., 2014; Scanlon et al., 2016). GRACE 
51 assimilated study has successfully outlined the trend and seasonality of groundwater storage

52 change (Famiglietti et al., 2011), allowed to calculate all terrestrial water balance components

53 (Rodell and Famiglietti 2001; Rodell et al., 2004; Tiwari et al., 2009), and used for evaluation of

54 the impact of climate change and drought (Famiglietti et al., 2011; Castle et al., 2014). This suits

55 the application of GRACE data to groundwater and soil moisture studies, especially in data

56 scarce regions.

57

58 However, the spatial resolution of GRACE is quite coarse, $400 \mathrm{~km}$ (Landerer et al., 2012.

59 Rodell. et al., 2002), and hence it only helps to evaluate the regional terrestrial water storage

60 changes. This limits the application of GRACE data for water resources allocation and

61 management at small watersheds scale (Moore and Fisher, 2012). In filling the gap between lack

62 of hydrological records and the requirement of sound knowledge-base in local and regional water

63 resources planning and management, downscaling and redistribution of the analysis results to

64 watershed scale is mandatory.

65

66 In the Tana basin, Ethiopia, groundwater monitoring system is not established. Hence, any

67 information that would be relevant to groundwater resources study is scarce. Due to lack of

68 information on how the groundwater system behaves, the use of the resources is based on

69 traditional methods. It is observed that the sustained decline of the groundwater table and the

70 decreasing trend of groundwater production wells is a common phenomenon. This calls for an

71 urgent understanding of the groundwater reserve in the area. Therefore, reliable information

72 derived from emerging technology options, such as remote sensing products, is mandatory to

73 evaluate and understand the groundwater distribution in the basin. 
74 Hence, the objective of this study is to evaluate the representativeness of GRACE driven change

75 in total terrestrial water storage at watershed scale in the Tana basin. Further, this study

76 attempted to redistribute the GRACE change in storage record at local scale to identify hotspots

77 of significant storage variability by using aquifer potential zones of the basin.

\subsection{Description of Study Area}

80 The Tana basin, Ethiopia, with a catchment area of $15,000 \mathrm{~km}^{2}$ and four major tributary rivers

81 (Fig. 1) forms one of the sixteen basins of the Blue Nile River Basin in Ethiopia. Mountainous

82 landscape surrounding flat lowland, the Lake Tana forms the center of the basin. The basin has a

83 unimodal rainfall regime, ranging of from $865 \mathrm{~mm} 2300 \mathrm{~mm}$ per year.

Insert Figure 1 here.

85 The basin exhibits porous medium fractured unconfined aquifer system where groundwater

86 recharge from mountainous regions flows into the gently laying lowland. The lowland,

87 surrounding by the Lake Tana water body, is a major groundwater reserve zone of the basin

88 (Nigate et al., 2016; Ayenew, et al., 2008). The aquifers are only rarely connected to the Lake

89 Tana water body, and hence aquifers and the lake interaction is only through surface flow

90 (Kebede et al., 2006). Overall, total terresterial water storage of the basin is dominantly a

91 function of groundwater recharge-discharge relation and soil moisture fluctuation.

92

\subsection{Dataset}


95 For delineation of aquifer potential zones, the local geological data, soil type, rainfall, and digital 96 elevation model (DEM) were used. Categories in each layer are converted into numerical scales

97 as 'Layer Classes'. These layer classes allow evaluation of the relative internal variations within

98 each layer in the context of groundwater holding and transmission capacity. The details of the 99 description of data are given below.

\subsubsection{Geology}

102 The dominant part of the basin is covered by two major geological formations, the Tarmaber 103 Basalts and Basalts related to volcanic center (BECOM, 1998; Chorowiz et al.,1998). The 104 Tarmaber Basalt covers the northern, western part and the southern end of the basin (Fig. 2). The 105 lowland covered by thick Quaternary Alluvial deposit, lacustrine deposits and Colluvium forms 106 the major aquifers zone. Basalts related to volcanic centers predominantly containing scoriaceous 107 basalt covers the southern part of the Tana basin. As indicated on the geological map (Fig. 2), 108 the Amba Aiba Basalts, Lateriteon Amba Alaji Rhyolite and Ashangi Basalts are sparsely 109 distributed in the basin.

111 Hydrogeologically, there are three major aquifer systems, the Tertiary Volcanic, the Quaternary 112 Fractured Vesicular Basalt and the Quaternary Alluvial deposits (SMEC, 2007; BECOM, 1998, 113 SOGREAH, 2013). The south part with Quaternary Basalt overlain by Alluvial Deposit exhibits 114 the highest productive aquifer. Whereas, the northern, southern and eastern mountainous regions, 115 mostly covered by highly degraded tuff and massive basalt, are characterized by lowest 116 productivity (SOGREAH, 2013). 
119 With this information, the geologic units (Fig. 2a) are changed into numerical index values as

120 'Geology Class' (Fig. 2b), following the aquifer medium rating approach of the DRASTIC

121 analysis (Aller et al., 1987). Accordingly, the rating value of 1 corresponds to impervious

122 geologic units and rating of 10 is assigned to highly pervious geologic units. Hence, the geologic 123 class values represent the measure of the degree of geologic units to act as an aquifer; the higher 124 the number, the higher the geologic unit can be a productive zone.

127 The Tana basin is covered by a wide range of soil types, as indicated in the soil databases of the 128 area (Fig. 3a); originally developed by BECOM (1998). According to the description and 129 hydrological grouping by SMEC (2007), the upslope region is covered by soils with higher 130 infiltration and drainage capacity. The floodplain to the north and east of Lake Tana is covered 131 by thick clay layer, which presents a lowest infiltration capacity. However, the soil in the 132 southern flood plain is covered by rock fragment that has higher infiltration capacity.

$$
\text { Insert Figure } 3 \text { here }
$$

134 Following the soil hydrological grouping of SMEC (2007), the soil map of the basin (Fig.3a) is 135 changed into numerical index values (Fig. 3b) based on the rating approach proposed by the 136 DRASTIC analysis (Aller et al., 1987). These numerical index values of the Hydrological soil 137 group (HSG) represent the relative rating of soils infiltration and drainage capacity. Soils with 138 high infiltration and drainage capacity receive high rating value and vice versa. As high rating 
139 value represent sites of high infiltration and drainage capacity, it implies high groundwater

140 recharge zones.

\subsection{Rainfall Distribution}

143 The Tana basin receives an effective three-month rainfall from June to September and areal

144 distribution varying from $866 \mathrm{~mm}$ to $2300 \mathrm{~mm}$ (Fig. 4a).

146 The southern parts of the basin have the highest annual precipitation, and the northwest has the

147 lowest. For this study, the rainfall data was scaled from one to hundred, according to Eq. 1; and

148 the scaled rainfall distribution (Fig. 4b) is used as index value to delineate the aquifer potential 149 zone of the basin.

$$
X_{\text {normal }}= \begin{cases}\frac{X-X \min }{X \max -X \min } & X \max -X \min >0 \\ 0 & X_{\max }-X_{\min }=0\end{cases}
$$

Where:

- $X$ is the original pixel value

- $X_{\text {normal }}$ is the normalized pixel value.

- $X_{\max }$ is the maximum pixel value of the layer under consideration for the basin. 
156 Accordingly, highest scale values are assigned to the corresponding area with high rainfall

157 distribution. Hence, these areas are associated with high groundwater recharge and high aquifer

158 potential zone.

\subsubsection{Digital Elevation Model (DEM)}

161 The 90 m resolution Shuttle Radar Thematic Mapper Digital Elevation Model (SRTM DEM)

162 (USGS-GMTED, 2010) is used to develop elevation difference, drainage density, slope class, 163 and topographic index layers which are further scaled from 1 to 100 (Eq. 1). Each of the scaled 164 layers is reclassified into five classes based on their geometric distribution (Fig. 5).

165 In the Tana basin, the high topographic elevation zone is a groundwater recharge zone. The 166 lower topographic elevation zone is a groundwater discharge zone that is manifested through 167 seep zones, wetland and springs (Engda et al., 2007; Kebede et al., 2006; Kebede et al., 2005). 168 As a result of these conditions, the lower elevation zone presents a high groundwater potential in 169 the area. This implies that elevation is inversely proportional to groundwater reserve zones, 170 therefore the lowest elevation zones receive higher value of the scaled elevation class and vice 171 versa (Fig. 5a).

173 Given the unconfined nature of the highly fractured medium of the Tana basin, topographic slope 174 controls the rate of groundwater flow in the subsurface (Engda et al., 2007; SMEC, 2007). Steep 175 slope favors runoff and/or an accelerated subsurface flow and gentle slope allows the 176 accumulation of groundwater. Accordingly, the slope is inversely proportional to aquifers 
177 potential and hence the inverse of the normalized slope is (Fig. 5b) deployed to define 178 groundwater potential zone of the area.

180 In addition to topography, the nature of the geologic material determines the type and density of 181 the drainage. In the Tana basin, highland zones have typical box drainage pattern; whereas, 182 streams at the floodplains have meandering pattern. The lowlands are highly characterized by 183 zones of spring emanation, such as the Lomi and Areki springs of the southern part with a 184 discharge of up to 106 1/s to 200 1/s (Nigate et al., 2016). Also, several small streams and gullies 185 are saturated at lowland areas, and these are formed by shallow and saturated subsurface flow of 186 groundwater (Tebebu et al., 2010; Abiy, 2009). Although the drainage density of the basin shows 187 small variation with location, it is considered to be directly proportional to groundwater 188 accumulation. High drainage density is proportional to high groundwater reserve and vice versa. 189 The normalized and geometrically reclassified drainage density map (Fig. 5c) is deployed for 190 aquifer potential zonation of the basin, accordingly.

192 Evaluation of the distribution of wetness through the Topographic Index (TI) framework (Beven 193 et al., 1984; Beven and Kirkby, 1979) is widely applied to hillslope hydrologic studies (Lyon et 194 al., 2006; Lyon et al., 2004; Schneiderman et al., 2007; Walter et al., 2002). As the TI (Eq. 2) 195 increases with increasing upslope contribution area and decreasing slope, it is known to 196 effectively remarket zones where shallow groundwater accumulates and forms saturation. At soil 197 saturation, runoff and groundwater recharge happen simultaneously. Hence, sites with high TI 198 define shallow groundwater accumulation zones that would lead to runoff and/or groundwater 199 recharged. Implying, TI is directly proportional to groundwater recharge and accumulation. 


$$
T I=\ln \left(\frac{\alpha}{\tan \beta}\right)
$$

201 Where: TI is the topographic index. $\alpha$ is the upslope contributing area per unit length of contour.

$202 \beta$ is the topographic slope of every cell. To avoid division by zero, the zero slope areas are 203 changed by $10^{-3}$.

204

205 For this study, the SRTM 90 DEM is processed in ArcGIS to develop topographic index map of 206 the Tana basins. The result is normalized to a scale of 1 to 100. As a result, the normalized TI 207 map of the area is reclassified into five classes according to its geometric distribution (Fig. 5d) 208 and this is deployed to delineate groundwater potential zones of the area. As a result, high TI is 209 proportional to high groundwater reserve and low TI is proportional to lower groundwater 210 reserve.

\subsection{Defining Groundwater Potential Zones}

213 A weighted index map of the seven thematic layers develops the potential groundwater reserve 214 zones within the basin. For an overall summation of the individual layers, the thematic layer's 215 relative weight (Wi) is defined by using pairwise comparison matrix (Satty, 1980). Besides field 216 knowledge of the area, the pairwise comparison is assigned based on similar studies elsewhere 217 (Fenta et al., 2014; Kumar, 2007). Hence, a GIS-based multi-layer analysis, as indicated in the 218 chart (Fig. 6), is applied to define groundwater potential zones within the basin. The overall 219 weighted index map is developed as:

$$
A P Z=\sum_{i=1}^{n}(R c)_{i} * W_{i}
$$

221 Where: $\mathrm{APZ}=$ Aquifer Potential Zone overall index, $\mathrm{Rc}=$ Rate of the classes within every thematic layer, $\mathrm{i}, \mathrm{Wi}=$ Weight of the thematic layer, $\mathrm{i}$. 
224 Furthermore, the overall weighted index is qualitatively interpreted as five classes of

225 groundwater potential zones. This allows scrutinizing the areas with different levels of aquifer

226 potential, where the high groundwater potential zone implies a high capacity of the aquifer to

227 store and transfer water and hence a high change in storage and vice versa.

228

229

230

231

232

233

234

235

236

237

238

239

240

241

242

243

244

245

\subsection{Combining GRACE with Local Aquifer Potential Zone}

For this study, we have used the GRACE change in total terrestrial water storage ( $\Delta \mathrm{TWS}$ ) data from University of Texas Center for Space Research release five (GRACE CSR RL05). GISbased resampling of this $110 \mathrm{~km}$ by $110 \mathrm{~km}$ (Fig. 7a) into $90 \mathrm{~m}$ x $90 \mathrm{~m}$ pixel size allows to effectively delineate the GRACE CSR RL05 that is incorporated in the basin (Fig. 7b). The resampling further allows for calculating the total $\triangle \mathrm{TWS}(\mathrm{cm})$ of the basin. Accordingly, the sum of the GRACE (CSR RL05) pixel values that are included within the basin is the net $\Delta$ TWS (cm) of the basin for the corresponding month. The monthly basin's $\Delta$ TWS (cm) is calculated for the time period 2004 to 2013. Some missing data within this time range are filled by averaging and/or applying the corresponding month value from other times.

\section{Insert Figure 7 here}

In the case of the Tana basin, the total terrestrial water storage is the sum of the change in water storage derived from the groundwater reserve, soil moisture, and surface water bodies. The Lake Tana water body is $3,000 \mathrm{~km} 2$ area, accounting about $20 \%$ of the basin's total area. Hence, the lake level fluctuation is significant in the evaluation of the $\Delta$ TWS . Lake level fluctuation data presented in SMEC (2007) and additional data from the Tana Sub-basin office are used to calculate the monthly anomalies of lake stage. The GRACE (CSR RL05) $\triangle$ TWS is equal to the 
246 sum of change in groundwater storage $(\mathrm{GwS})$, change in soil moisture (SoM) and change in 247 surface water reserve $(\mathrm{SwR})$ in depth units $(\mathrm{cm})$. Hence, the change in storage of the basin's 248 groundwater and soil moisture is the difference between the GRACE (CSR RL05) $\triangle$ TWS and 249 the respective month change surface water storage (SwR, Eq. 4).

$$
\mathrm{GwS}+\mathrm{SoM}=\Delta \mathrm{TWS}-\mathrm{SwR}
$$

251 The SwR is the sum of the change in storage from stream channels and Lake Tana storage.

252 However, the dominant SwR of the basin is driven from the change in storage of the Lake Tana 253 water body; whereas, the change in storage from stream channels is insignificant. For such 254 analysis, given the time resolution of GRACE (CSR RL05), the SwR has been considered as the 255 change in storage from surface water reservoirs only (Long et al., 2013). Hence, the Lake Tana 256 monthly change in lake level is used in terms of SwR (cm).

258 Overall, for spatial redistribution of the GRACE (CSR RL05) $\Delta$ TWS (cm) at the watered scale, 259 the following simplified assumptions were made.

260 - The change in total terrestrial water storage of an area on the ground surface represented by a pixel in GRACE (CSR RL05) $\triangle$ TWS (cm) is not uniformly distributed within the area at the ground surface;

- Some part of the area, at the ground, with high aquifer potential can show the larger gain or loss than the change in storage recorded by GRACE (CSR RL05) $\Delta$ TWS (cm); whereas, part of the area with limited aquifer potential do not have significant change in 266 storage. 
- The monthly GRACE (CSR RL05) $\triangle$ TWS of the Tana basin is the sum of the monthly changes in groundwater, soil moisture, and surface water storage changes. Given the duration and scale of observation of the GRACE (CSR RL05) $\triangle$ TWS and considering the quick runoff response and size of the basin, the surface water change in storage is defined by the change in stage of the Lake Tana, only.

Accordingly, the overall gain or loss of the groundwater storage from the area is a factor of the relative index value of every pixel as compared to the overall basin's aquifer potential index. Hence, this relative index value of every pixel, for simplicity, is called Fractional Pixel Value (FPV) and was calculated based on Eq. 5 as:

$$
\mathrm{FPV}=\frac{\mathrm{APZ}_{\mathrm{i}}}{\sum_{\mathrm{i}}^{\mathrm{n}} \mathrm{APZ}_{\mathrm{i}}}
$$

Where: FPV = Fractional Pixel Value is the relative proportion of every pixel to represent the groundwater reserve potential in the defend aquifer zone, and $\mathrm{APZi}=$ the pixel value of the Overall Aquifer Potential Zone Map.

The fractional pixel value represents the significance of each pixel within the aquifer potential zone layer to behave as a groundwater storage unit. The higher the Fractional Pixel Value the higher a pixel can represent sites that gain or lose water from storage.

\section{Results and Discussion}

\subsection{Aquifer Potential Zoning}


288 In this study, seven thematic layers were developed to delineate aquifers potential in the Tana 289 basin. To designate the internal layers rating, each thematic layer was reclassified into five 290 geometric classes. The relative weight of the individual layers is evaluated using pairwise 291 comparison matrix (Table 1).

293 According to this evaluation, the topographic index and elevation difference layers exhibit about $29430 \%$ of the weight to control the distribution of the groundwater reserve zone in the basin. The 295 Tana basin is predominantly characterized by rolling mountain terrain with numerous local 296 watersheds. With the unconfined shallow nature of the aquifer, it has pockets of aquifer zones 297 which are highly controlled by the upslope contributing area and its relative location with respect 298 to the overall basin. Hence, it is plausible that the topographic index and elevation difference 299 layers receive the higher weight.

300 There is sufficed amount of rainfall to recharge the aquifer all over the basin. As a result, rainfall 301 is not a limiting factor to define groundwater potential zone. Instead, the groundwater recharge in 302 the area is limited by the combined effects of slope, geology and soil cover. This latest three 303 layers, all together, account for more than $30 \%$ of the weight to control aquifer potential zones in 304 the basin.

306 The sum of the product of the thematic layer's rate with their relative weight (Eq.3) generates a 307 range of index values that imply the local distribution of aquifer potential zones and their total 308 index value (Fig. 8a). The overall index values range from 3 to 380. Smallest values represent 309 areas with limited capacity to reserve groundwater and vice versa. Accordingly, mountainous 
310 regions with steep slope and tuffaceous geologic unit zones have the lowest aquifer potential.

311 Lowlands, with highest flow accumulation zones and covered by pervious soil and geologic units

312 along gentle slope area have the higher aquifer potential. A range of intermediate index values is

313 recorded in western part as a control of the soil type and TI values.

Insert Figure 8 here

315 The ten class aquifer potential index value (Fig. 8a) is geometrically reclassified into five 316 qualitative aquifer storage potential zones (Fig. 8b). Accordingly, the southern part of the Tana

317 basin, with its higher topographic index, porous vesicular basaltic cover, and low lying flat

318 topography, has the highest aquifer potential. This implies a potential for high change in storage

319 variability over the shallow unconfined aquifer in the locality. The eastern lowland area, despite

320 its highest topographic index, has a thick clay layer which limits its groundwater storage

321 potential. Moreover, the mountain regions, at all sides, have lower groundwater storage potential.

323 Overall, the aquifer's potential zone delineation result well matches with previous regional

324 studies by Ayenew et al. (2008) and SOGREAH (2013). However, this result has some 325 advantages with a better resolution $(90 \mathrm{~m})$, and the fact that it is digitized allowing for further 326 analysis to downscaling of the GRACE data.

\subsection{Spatial redistribution of the GRACE $\triangle T W S$}

329 The spatial distribution of the monthly change in total terrestrial water storage $(\Delta \mathrm{TWS})$ indicate that the downstream areas, delineated as high and very high Aquifer Potential Zones (Fig. 8b),

331 show most of the monthly total storage changes observed by the GRACE (CSR RL05). The 
332 redistributed monthly change in storage result (Fig. $9^{2}$ ) shows that these sites exhibit the highest 333 gain and loss of the total terrestrial water storage within the basin. These sites are typically

334 characterized by high topographic index and contain porous basalt. Considering the change in 335 groundwater and soil moisture storage is a replica of this $\Delta \mathrm{TWS}$, these sites are the hotspots that 336 show the significant change in groundwater and soil moisture storage. Besides that, these sites 337 have a rapidly increasing but slowly decreasing pattern of the monthly $\Delta$ TWS. Over all, the area 338 to the south of the Lake Tana is the highest Aquifer Potential Zone of the basin, and this is the 339 hotspot where the storage fluctuation is the highest.

341 On the other hand, mountain regions show a small range of $\Delta \mathrm{TWS}$ fluctuations. The impervious 342 nature of the tuffaceous geology, steep slope and limited topographic index has defined this area 343 to be the lowest aquifer potential zone. As a result, despite rainfall availability the aquifer 344 potential is limited and its storage fluctuation is infinitesimal. Further, low fluctuations of storage 345 are also observed in the downstream area of the basin. Areas where the geology is covered by 346 impervious formations, and/or thick clay layer and availability of abrupt change in the 347 topography have triggered poor to low aquifer potential zones within the downstream area of the 348 basin. Over all, these sites, delineated as poor and low aquifer potential zones (Fig. 8b) at 349 mountain regions and lowland areas, show a small range of $\Delta \mathrm{TWS}$, and they exhibit quick shift between gain or loss in TWS.

\footnotetext{
2 figures label 'a' refer the original GRACE (CSR RL05) data and the figures label ' $b$ ' are the redistribution product of the corresponding month.
} 
351 The GRACE (CSR RL05) is in depth (cm) unit, whereas the numbers on the re-distribution map

352 (Fig. $9^{3}$ ) represent the relative proportion of change in storage. Negative values refer to loosing 353 stage, and positive values represent gaining stage of the change in total terrestrial water storage.

354 The magnitude of the numbers represents the level of loss or gain. It doesn't refer to the actual 355 depth of change in storage, however.

356 Insert Figure 9:

${ }^{3}$ figures label 'a' refer the original GRACE (CSR RL05) data and the figures label ' $b$ ' are the redistribution product of the corresponding month. 


\subsection{Long Term $\Delta$ TWS}

362 The total monthly change in soil moisture and groundwater storage shows cyclic gain and loss

363 (Fig. 10), consistent with the seasonal rainfall pattern of the area. The decrease in water storage 364 stage of the basin is consistent with dry season. Studies indicate similar findings, in the Gilgel 365 Abbay catchment of the basin (Enku et al., 2014). They have found a declining stream discharge

366 in dry season and concluded that the dryness of the Gilgel Abbay River is driven by declining 367 groundwater recharge and discharge. Likewise, a GRACE based groundwater study of the 368 Amazon basin (Frappart et al., 2013) indicates cyclic gain and loss of groundwater storage 369 consistent with the rainfall pattern of the area.

\section{Insert Figure 12 here}

371 The watershed changes in soil moisture and groundwater storage lags behind the peak rainfall of 372 the area. The maximum precipitation is in July, while the GRACE change in total water storage 373 rises to the maximum in August to September. After September, the groundwater system gains at 374 a decreasing rate until November. Most of the records indicate that the change in storage 375 becomes zero at November. This reflects that the groundwater system is totally dependent on 376 local recharge. Furthermore, the decreasing trend of the groundwater storage change occurs 377 during the dry season. Likewise, the losing stage of the groundwater reserve drives the low flow 378 condition of the streams. Based on this, it is evident that soil moisture and groundwater storage

379 variability is driven by local precipitation, whereas the dry season environmental flow 380 requirement is dependent change in storage of the aquifers (Enku et al., 2014). 
382 The 11-year monthly change in storage indicates that the basin has a wide range of change in 383 total storage fluctuation (Fig. 11a). This period's total annual stoarge indicates six out of the 11 384 observation years exhibit dryness in net soil mositure and groundwater storage (Fig. 11b).

\section{Insert Figure 13 here}

386

387

Although the annual changes in storage is consisten with the rainifall pattern, the net annual groundwater and soil moisture storage change of the total study period indicates that the Tana basin has an ultimate loss of $18.37 \mathrm{~cm}$ within in the hydroperiod 2003 to 2013. Considering the basin $15,000 \mathrm{~km}^{2}$ area, this is equavalent to a net loss of $2.21 \mathrm{BCM}$ of water. Analysis on the causes of the groundwater and soil mositure storage changes is not considerd under this study.

\section{Conclusion and Recommendation}

\subsection{Conclusion}

Besides a good agreement with previous studies, the aquifers potential evaluation in this study is made with a better spatial resolution, hence it can be useful for local groundwater investigation, development and management. More importantly, the raster nature of the aquifer potential index map developed in this study is effectively deployed to redistribute the GRACE change in total terrestrial water storage information. As a fact, the study has presented an admonitory approach to refining and extracting groundwater storage changes from the GRACE database.

\section{Based on this, the downscaled GRACE driven change in watershed water storage information} has a good agreement and a strong implication to the aquifer system. The increasing groundwater storage is driven by precipitation with some lag time. Hence, the area is predominated by unconfined aquifers that have inter-annual variability of water storage as a reflection of the 
404 rainfall. Likewise, the losing stage of the groundwater reserve drives the low flow condition of

405 the streams. Therefore, it is evident that the streams are highly dependent on the change in 406 groundwater reserve of the area.

\subsection{Recommendation}

409 The time series analysis indicates an overall declining trend in soil moisture and groundwater

410 storage change in the basin. Hence the declining groundwater reserve trend is evident. As a fact,

411 a sustainable use of the groundwater resource of the basin should be based upon an informed

412 decision on the overall aquifer storage and productivity. In addition, facilitation of groundwater

413 recharge mechanisms and soil moisture harvesting system are highly recommended.

414 For further application of the redistribution products to monitoring and evaluation of changes in

415 groundwater resources at local scale, it is recommended to evaluate the results using local

416 ground based information on groundwater and soil moisture. It is recommended to incorporate

417 groundwater and soil moisture monitoring data to the results of redistribution of GRACE (CSR

418 RL05).

420 Acknowledgment

421 We are grateful to the Department of Earth and Environment, Florida international University for

422 the financial support, computer and lab facilities used for this study. Part of the analysis of the

423 GRACE data is conducted in the working stations at the GIS and Remote Sensing Center of

424 Florida International University that would like to forward our gratitude. The study has deployed

425 different data from the Abbay Basin Authority and Tana Sub-basin office in Bahir Dar, Ethiopia 
426 and opens source information from USGS and Center for Space Research at the University of

427 Texas, Austin. Hence, we are grateful to our data sources.

\section{References}

429 Abiy, Anteneh Z., Solomon S. Demissie, Charlotte MacAlister, Shimelis B. Dessu, and Assefa M. Melesse. (2015). Groundwater Recharge and Contribution to the Tana Sub-Basin, Upper Blue Nile Basin, Ethiopia. Pp. 463-81 in Landscape Dynamics, Soils and

Abyi, Anteneh Z. (2009): Geological controls in the formations and expansions of gullies over hillslope hydrological processes in the Highlands of Ethiopia, northern Blue Nile region, A

Thesis Presented to the Faculty of the Graduate School of Cornell University in Partial Fulfillment of the Requirements for the Degree of Master of Professional Studies, Ithaca, Hydrological Processes in Varied Climates. NY.

Ahmed M., Sultan W., Wahr J., Yan E. (2014). The use of GRACE data to monitor natural and anthropogenic induced variations in water availability across Africa. Earth-Science

\section{Reviews 136, 289-300}

Aller, Linda; Bennett, Truman; Lehr, Jay H; Hackett, Glen; Petty, Rebecca J; Thornhill, Jerry. (1987). DRASTIC: A standardized system for evaluating groundwater pollution potential using hydrogeological settings. EPA 600/2-EP87/036. Ada, Oklahoma: National Water Wells Association. groundwater in the Ethiopian aquifers. Journal of African Earth Sciences 52 (2008) 97113. 
BCEOM. (1998). Abbay River Basin integrated master plan, main report. Ministry of Water Resources, Addis Ababa

Beven, K.J., Kirkby, M.J., Schofield, N., Tagg, A.F. (1984), A physically based flood forecasting model (TOPMODEL) for 3 UK catchments, Journal of Hydrology, 69:119143.

Beven, K.J. and M.J. Kirkby. (1979). A Physically Based, Variable Contributing Area Model of Basin Hydrology. Hydrol. Sci. Bull. 24: 43-69.

Castle, L. S. Thomas, F. B. Reager, T. J. Rodell, M. Swenson, C. S. and Famiglietti, S. J. (2014). Groundwater depletion during drought threatens future water security of the Colorado River Basin. Geophysical Research Letters 10.1002/2014GL061055.

Chorowiz, J., Collet, B., Bonavia, F., Mohr, P., Parrot, J.-F., Korme, T. (1998). The Tana basin, Ethiopia. Intra-plateau uplift, rifting and subsidence. Tectonophys. 295, 351-367.

Engida, Z. Yilma, S. \& Tuinhof, A. (2007). Groundwater resources in Lake Tana sub basin and adjacent areas, rapid assessment and terms of reference for further study. Federal Republic of Ethiopia/ World Bank.

Enku, T., Tadesse, A., Yilak, D.L. et al. (2014). Biohydrology of low flows in the humid Ethiopian highlands: The Gilgel Abay catchment. Biologia 69: 1502. doi:10.2478/s11756014-0462-9

Famiglietti, S. J. and Rodell, M. (2013). Water in the Balance. Science 14 JUNE 2013 VOL 340.

Famiglietti, J. S., Lo, M., Ho, S. L., Bethune, J., Anderson, K. J., Syed, T. H. ... \& Rodell, M. (2011). Satellites measure recent rates of groundwater depletion in California's Central Valley. Geophysical Research Letters, 38(3). doi:10.1029/2010GL046442 
471 Fenta, A. A. Kifle, A. Gebreyohannes, T. Hailu, G. (2014). Spatial analysis of groundwater

472

473

474

475

476

477

478

479

480

481

482

483

484

485

486

487

488

489

490

491

492 potential using remote sensing and GIS-based multi-criteria evaluation in Raya Valley, northern Ethiopia. Hydrogeology Journal. DOI 10.1007/s10040-014-1198-x

Frappart, F. Ramillien, G. and Ronchail, J. (2013), Changes in terrestrial water storage versus rainfall and discharges in the Amazon basin. Int. J. Climatol., 33: 3029-3046. doi:10.1002/joc.3647

Kebede, S., Travi, Y., Alemayehu, T. \& Ayenew, T. (2005). Groundwater recharge, circulation and geochemical evolution in the source region of the Blue Nile River, Ethiopia. Applied Geochemistry, 20(9), 1658-1676.

Kebede. S., Travi. Y., Alemayehu. T. Marc, V. (2006). Water balance of Lake Tana and its sensitivity to fluctuations in rainfall, Blue Nile basin, Ethiopia. Journal of Hydrology 316, $233-247$

Kumar P.K., Gopinath G., Seralathan P. (2007). Application of remote sensing and GIS for demarcation of groundwater potential zones of a river basin in Kerala, southwest coast of India. Int J Remote Sens 28(24):5583-5601

Landerer, F. W., and S. C. Swenson (2012). Accuracy of scaled GRACE terrestrial water storage estimates, Water Resour. Res., 48, W04531, doi:10.1029/2011WR011453.

Long, D., B. R. Scanlon, L. Longuevergne, A.-Y. Sun, D. N. Fernando, and H. Save (2013), GRACE satellites monitor large depletion in water storage in response to the 2011 drought in Texas, Geophys. Res. Lett., 40, 3395-3401, doi:10.1002/grl.50655.

Lyon, S.W., Lembo, A.J., Walter, M.T., Steenhuis, T.S. (2006). Defining probability of saturation with indicator kriging on hard and soft data. Adv. Water Resour. 29, 181-193. 
Lyon, S.W., Walter, M.T., Gérard-Marchant, P., Steenhuis, T.S. (2004). Using a topographic index to distribute variable source area runoff predicted with the SCS curve-number Eq. Hydrol. Process. 18, 2757-2771.

Moore, Scott and Joshua B. Fisher. (2012). Challenges and Opportunities in GRACE-Based Groundwater Storage Assessment and Management: An Example from Yemen. Water Resources Management 26(6):1425-53.

Nigate, F., Camp, M.V., Kebede, S., Walraevens, K., (2016). Hydrologic interconnection between the volcanic aquifer and springs, Lake Tana basin on the Upper Blue Nile. Journal of African Earth Sciences 121 154-167

Rodell, M., J. S. Famiglietti, J. Chen, S. I. Seneviratne, P. Viterbo, S. Holl, and C. R. Wilson (2004), Basin scale estimates of evapotranspiration using GRACE and other observations, Geophys. Res. Lett., 31, L20504

Rodell, M., and. Famiglietti, J. S (2001). An analysis of terrestrial water storage variations in Illinois with implications for the Gravity Recovery and Climate Experiment (GRACE), Water Resour. Res., 37, 1327-1340.

Rodell, M., and J. S. Famiglietti (2002). The potential for satellite-based monitoring of groundwater storage changes using GRACE: The High Plains aquifer, central U.S. J. Hydrol., 263, 245-256.

Saaty, T.L. (1980). The Analytic Hierarchy Process. McGraw-Hill, New York.

Scanlon, B. R., Z. Zhang, R. C. Reedy, D. R. Pool, H. Save, D. Long, J. Chen, D. M. Wolock, B. D. Conway, and D. Winester (2015), Hydrologic implications of GRACE satellite data in the Colorado River Basin, Water Resour. Res., 51, 9891-9903, doi:10.1002/2015WR018090. 
Schneiderman, E.M., Steenhuis, T.S., Thongs, D.J., Easton, Z.M., Zion, M.S., Neal, A.L., Mendoza, G.F., Walter, M.T. (2007). Incorpo-rating variable source area hydrology into a curve-number-based watershed model. Hydrol. Process. 21, 3420-3430.

SMEC. (2007). Hydrological study of the Tana-Beles sub-basins. Draft inception report. SOGREAH (2013). Groundwater Investigation and Monitoring in the Tana and Beles Sub Basins Stage 1. Final report. In: Part 6. Hydrogeologic Survey, vol. 11 (unpublished). Tebebu, T. Y., Abiy, A. Z., Dahlke, H. E., Easton, Z. M., Zegeye, A. D., Tilahun, S. A., Collick, A. S., Kidnau, S., Moges, S., Dadgari, F., and Steenhuis, T. S. (2010). Surface and subsurface flow effect on permanent gully formation and upland erosion near Lake Tana in the Northern Highlands of Ethiopia, Hydrol. Earth Syst. Sci. Discuss., 7, 5235-5265, doi:10.5194/hessd-7-5235-2010, 2010.

Tiwari, V. M., J. Wahr, and S. Swenson (2009). Dwindling groundwater resources in northern India, from satellite gravity observations, Geophys. Res. Lett., 36, L18401, doi:10.1029/2009GL039401.

USGS-GMTED EROS Data Center. http://dds.cr.usgs.gov/srtm/version2_1/SRTM3/Africa/ Wada, Y., L. P. H. van Beek, C. M. van Kempen, J. W. T. M. Reckman, S. Vasak, and M. F. P. Bierkens (2010). Global depletion of groundwater resources, Geophys. Res. Lett., 37, L20402, doi:10.1029/2010GL044571.

Wahr, J., Swenson, S., Zlotnicki, V., \& Velicogna, I. (2004). Time-variable gravity from GRACE: First results. Geophysical Research Letters, 31(11). Walter, M.T., Steenhuis, T.S., Mehta, V.K., Thongs, D., Zion, M., Schneiderman, E.(2002). Refined conceptualization of TOPMODELfor shallow subsurface flows. Hydrol. Process. 16, 2041-2046. 
539 Ward. A. 2004. Gravity Recovery and Climate Experiment (GRACE).

540 http://earthobservatory.nasa.gov/Features/GRACE/page1.php 


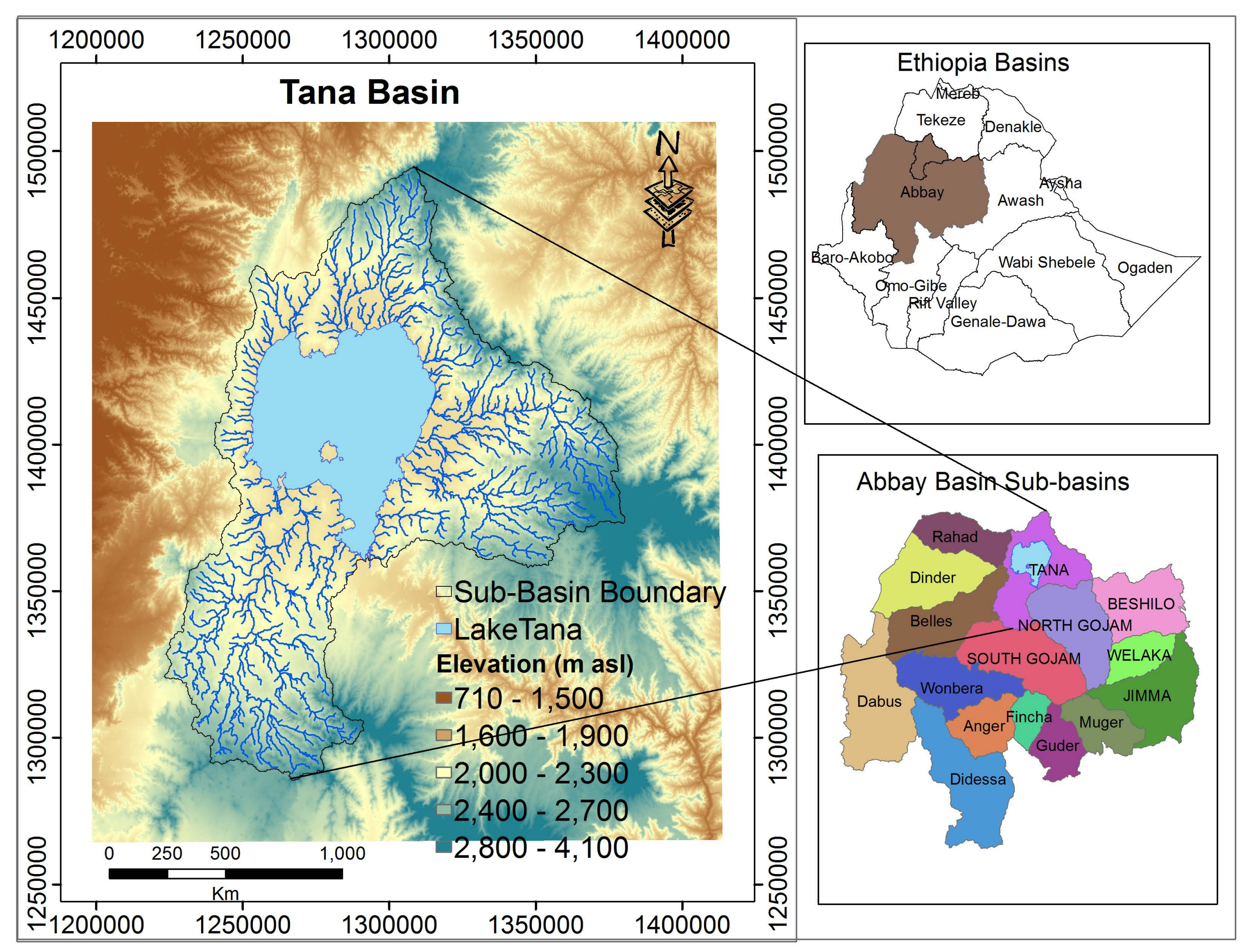



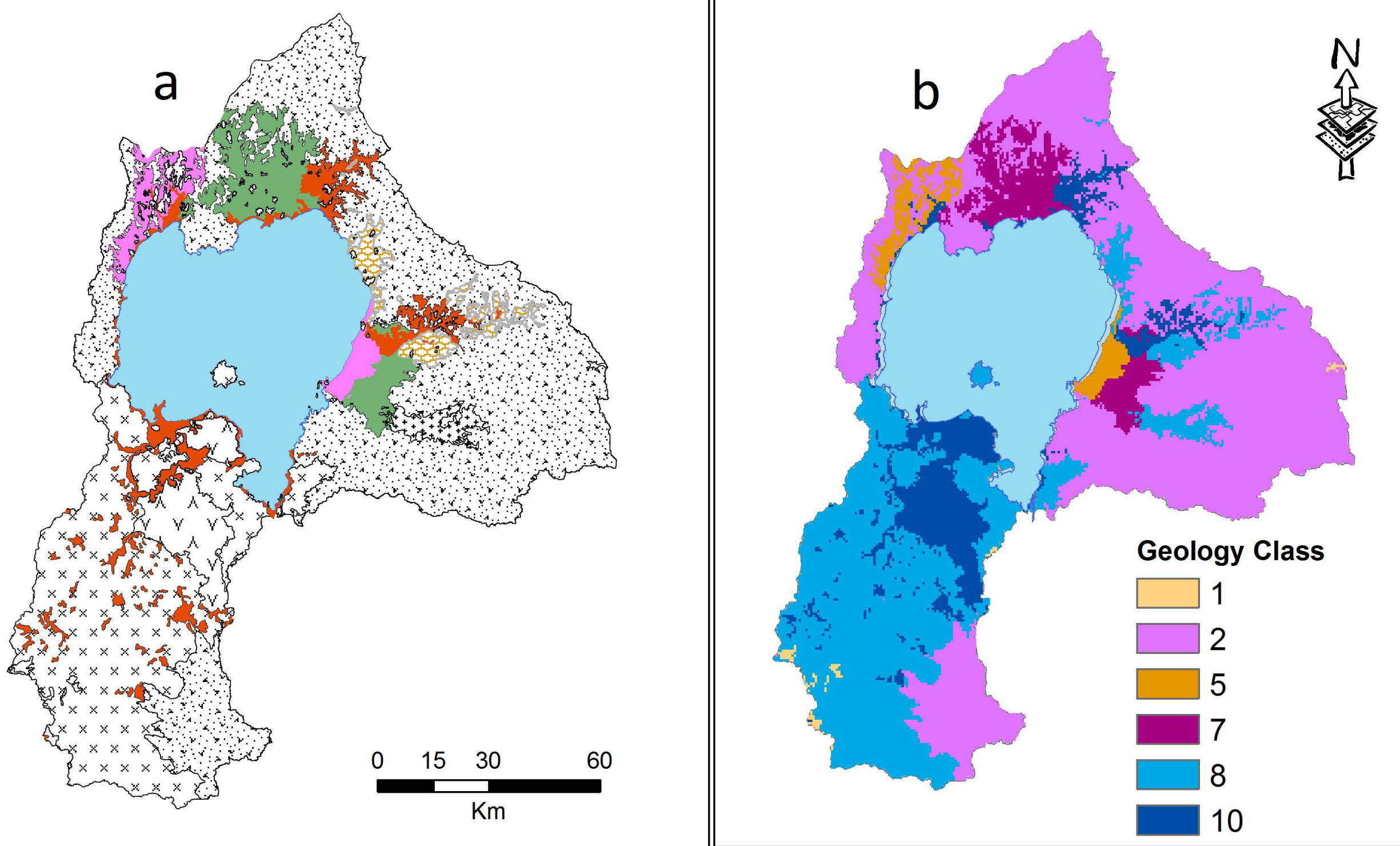

\section{Geology}

Alluvium

Amba Aiba Basalts

Ashangi Basalts

$x \times$ Basalts related to Volcanic centers (1) $x \times$ Basalts related to volcanic center (2) $\square$ Lake

Basalts related to volcanic centers (u) Lateriteon Amba Alaji Rhyolite

$\checkmark v$ Baselts related to volcanic center (3) Marsh soils

피되도 Coluvium

W. Termaber Basalts (2)

Lacustrine deposites 


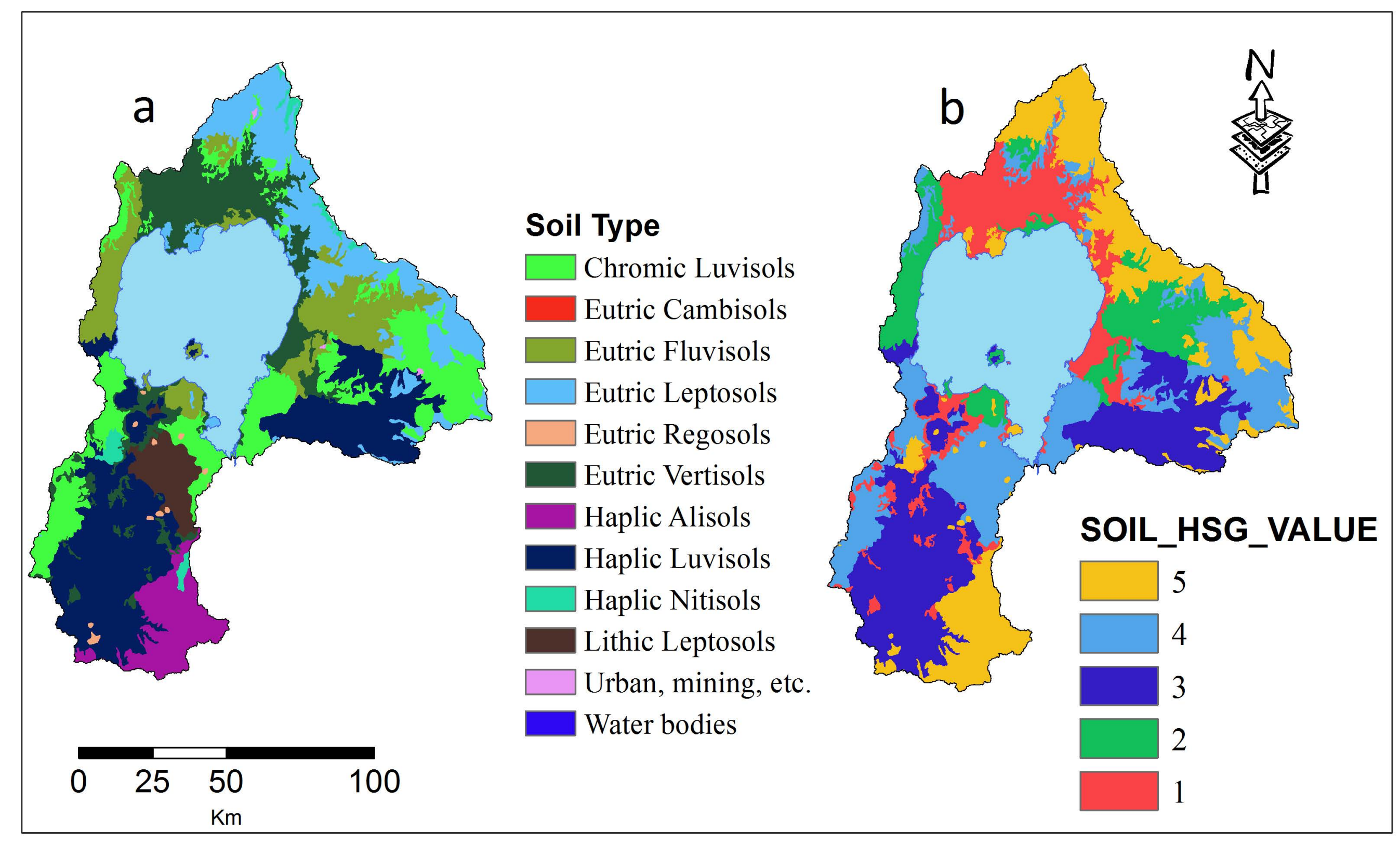




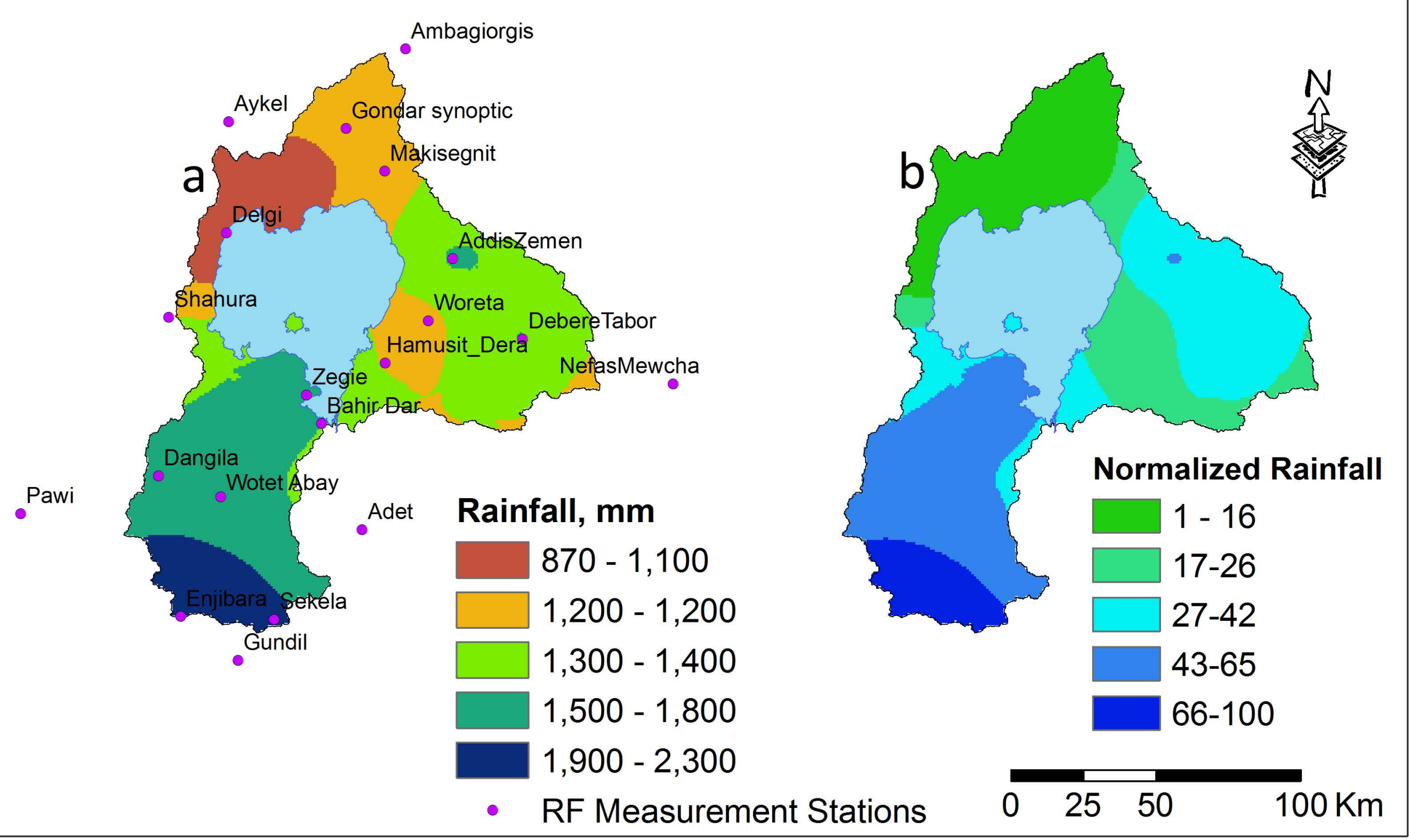




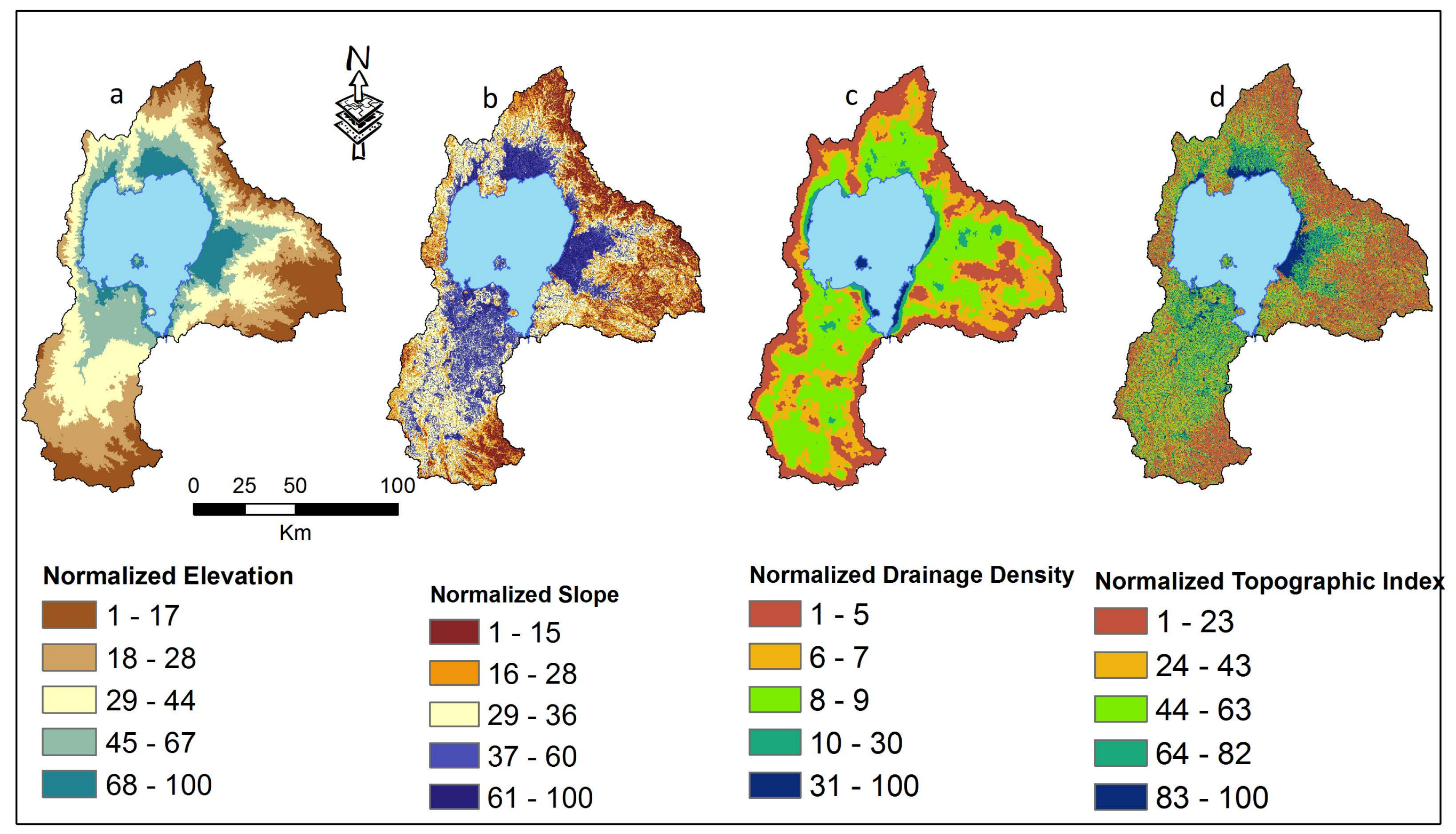




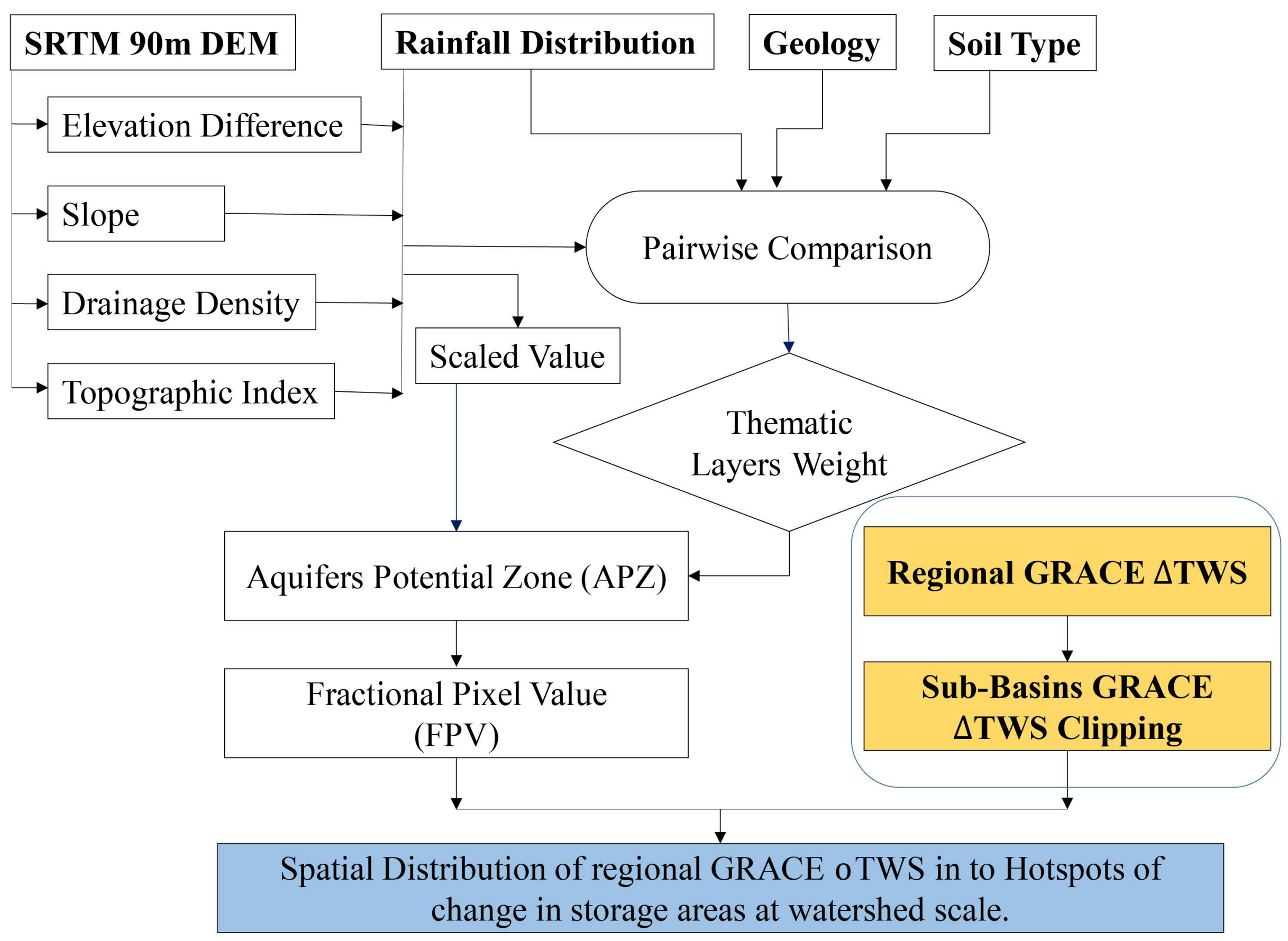



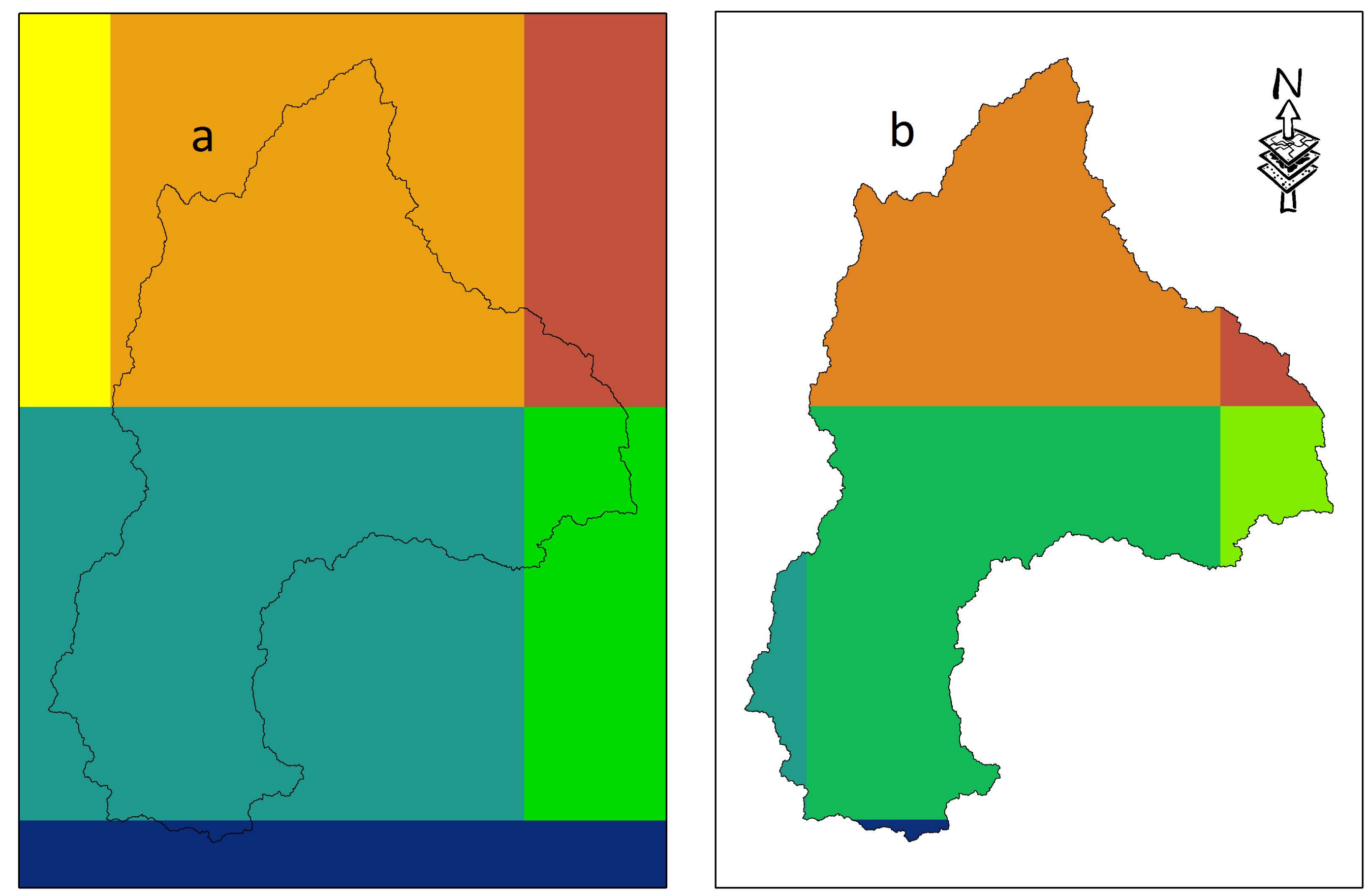

$\Delta$ TWS (cm)

$6.9-7.4$

$8.3-8.8$

$9.2-10$

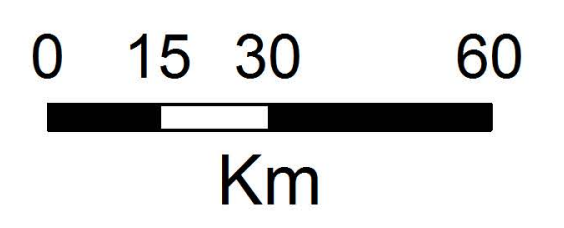




\section{Tana Basin Aquifer Potential Index and Aquifer Potential Zone}

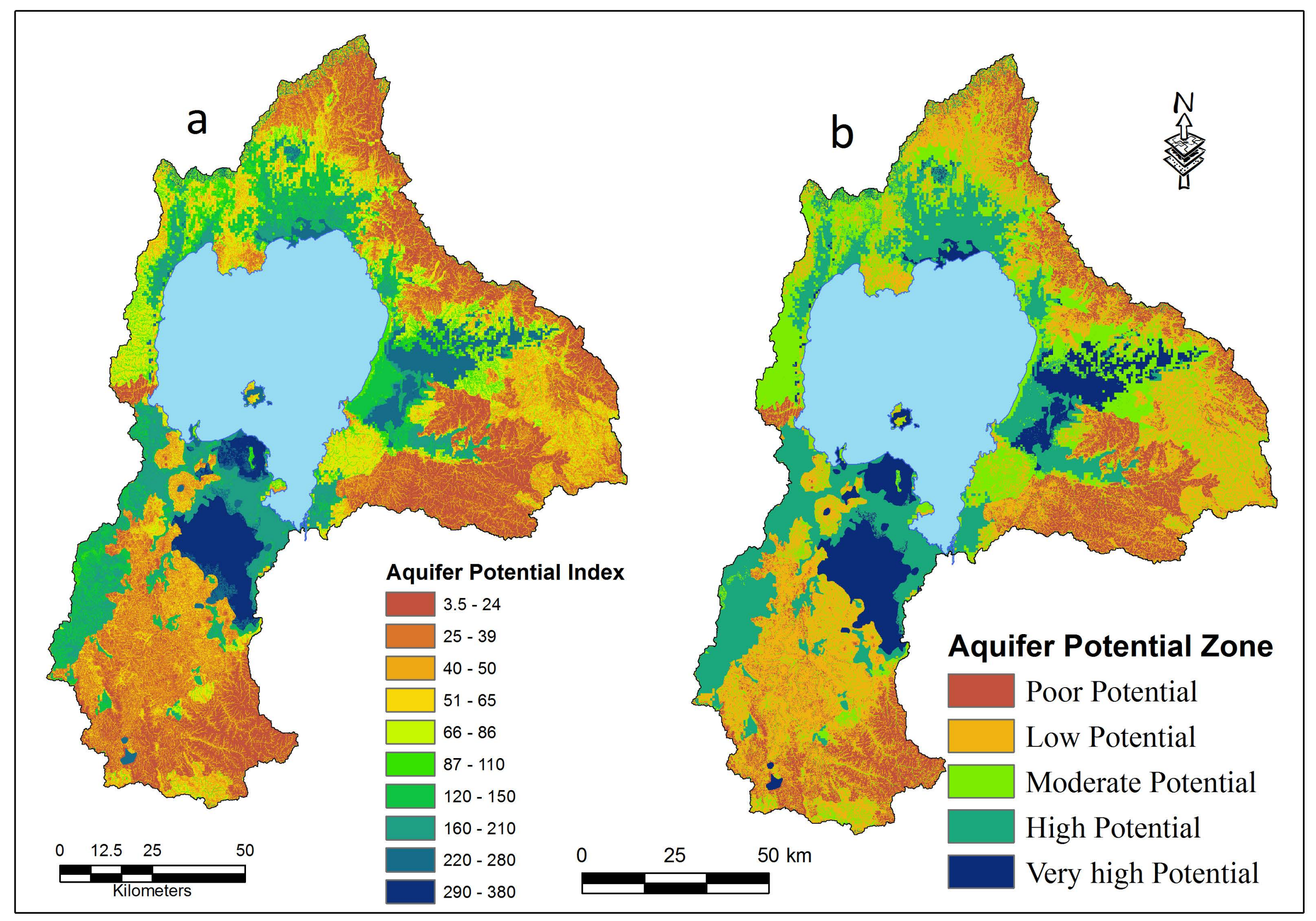



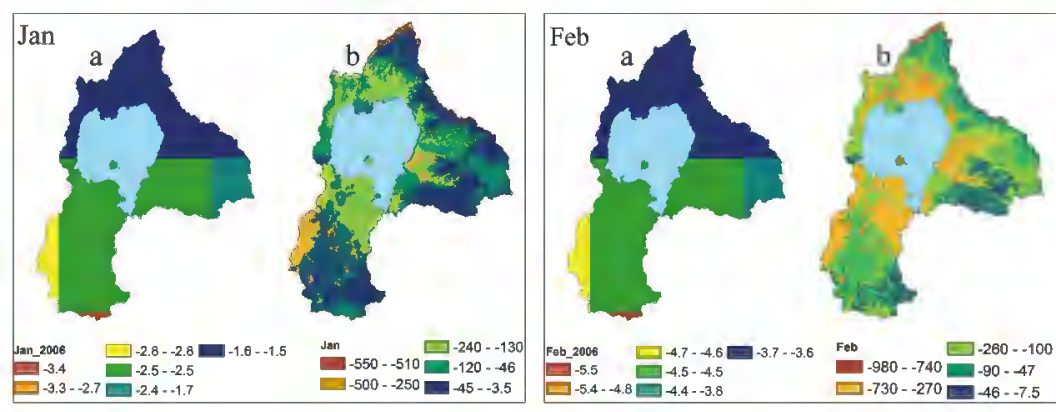

Apr
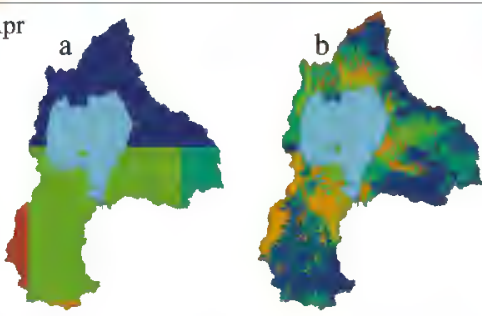

Apr_2006 $-7.1--6.4 \square-5.5--5.2 \mathrm{mpr}$

$-556.2--332.2$ $-7.2 \square-6.3-5.6 \square-5.1--4.5 \square-1,476--924 \square-332.1-125.4$
$-923.9 \cdot-556.3$

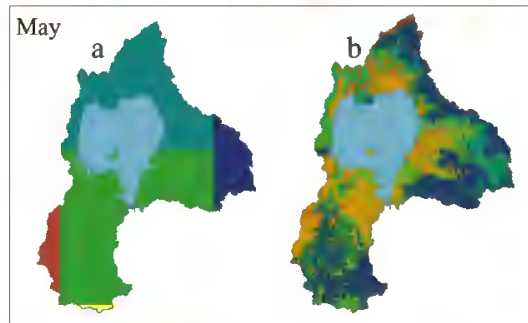

M⿻上_2008 $\square-6.5-6.5 \square-5.8--5$ $-7.1 \square-6.4--5.6$ -7.1
$-7-8.8$
$\square-5.7-5.5$

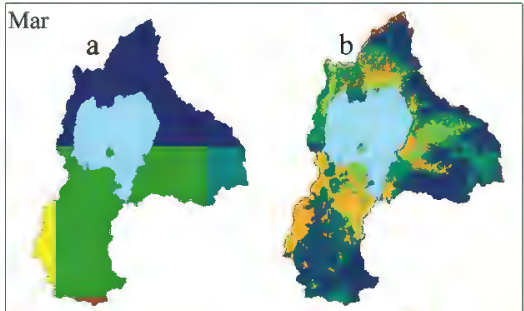

Mar_zo06 $\square-6.5--8.2 \square-4.8-4.3$ Mar $\square-539.7--311.9$ $-7.1$ $\square-7-6.6 \square-5.5--4.9$ $-884.1-539.8-128.3-0.835$

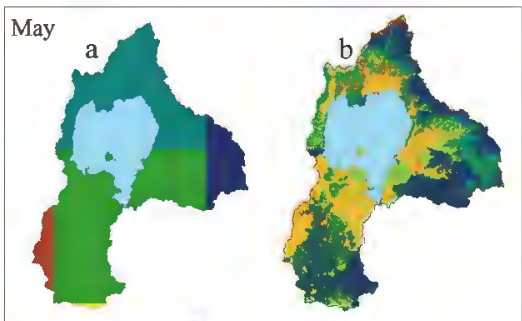

Mey_2005 $\square-6.5--6.5 \square-5.6--5$

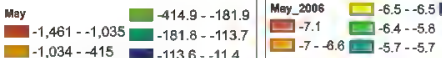

May

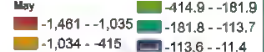




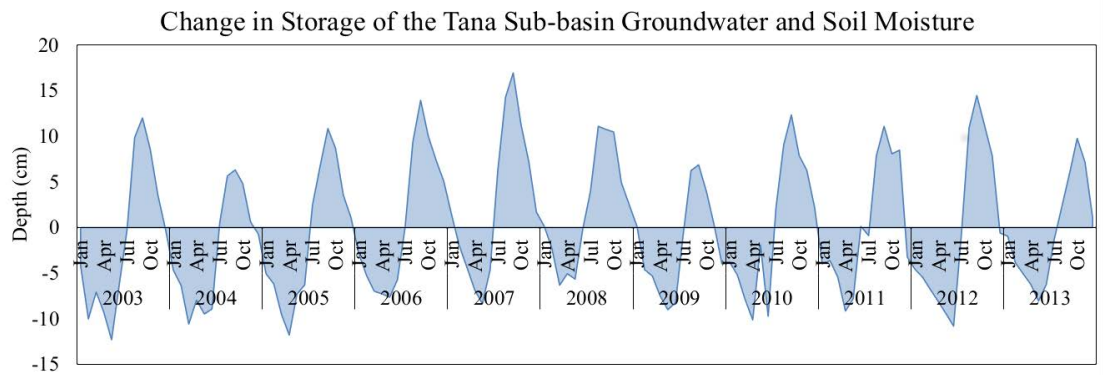




\section{Inter Annual Change in Storage Variability}

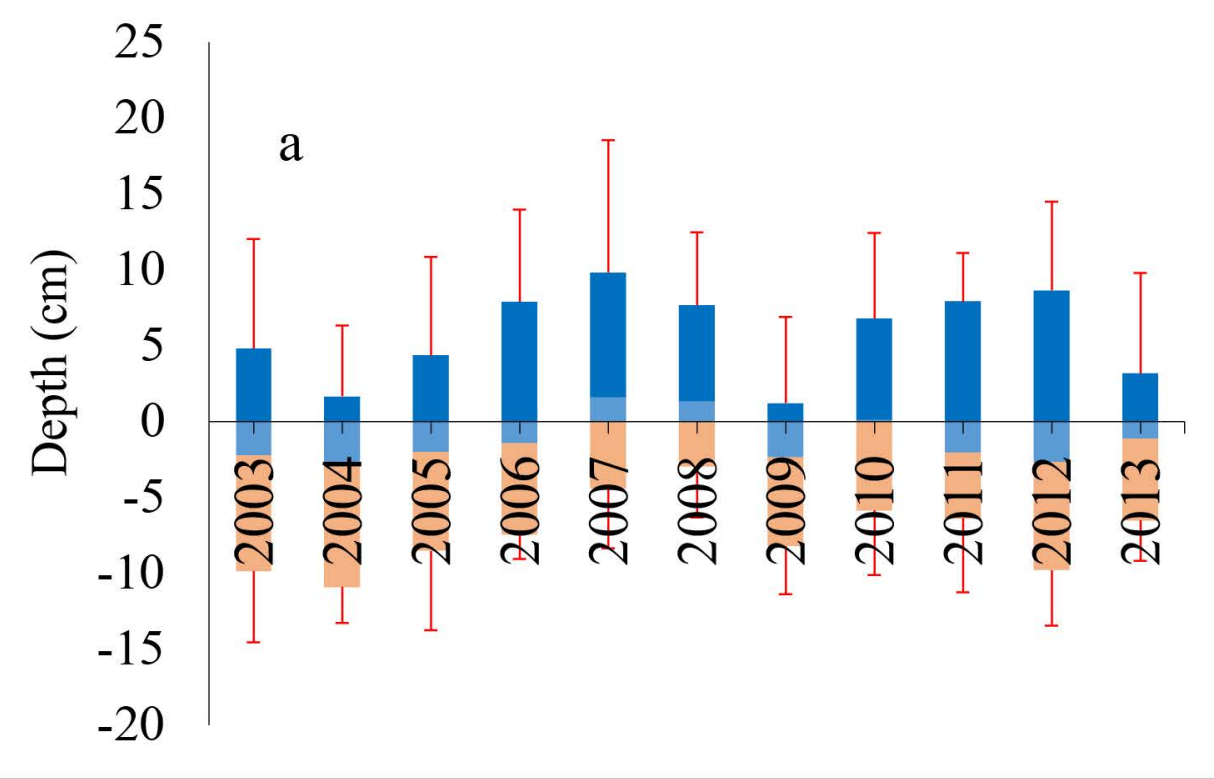

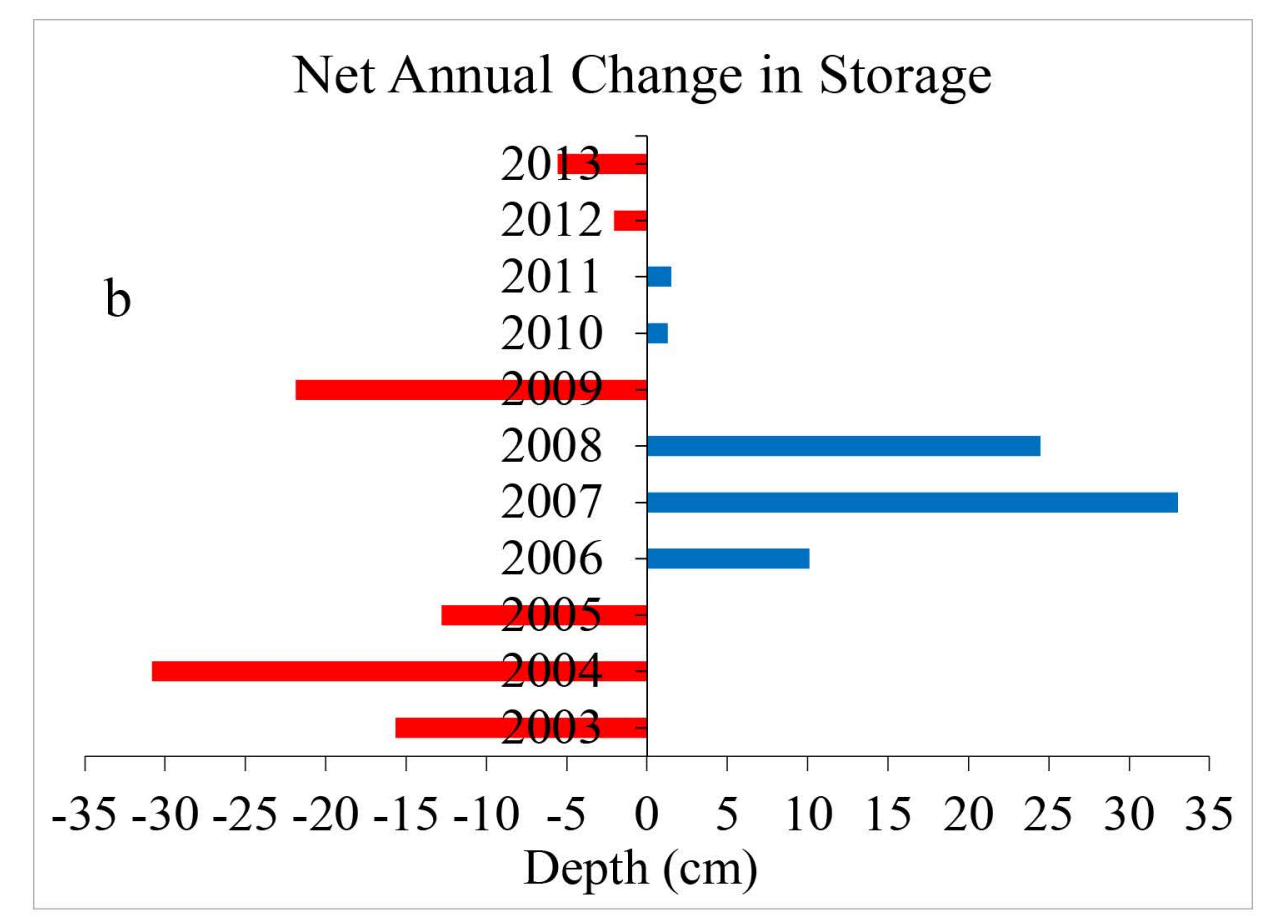


Table 1. Pairwise comparison matrix of the layers used for aquifer potential zonation

\begin{tabular}{lcccccccc}
\hline Description & TI & $\begin{array}{c}\text { Elevation } \\
\text { Difference }\end{array}$ & Slope & $\begin{array}{c}\text { Drainage } \\
\text { Density }\end{array}$ & Soil & Geology & Rainfall & Weight \\
\hline TI & 1 & 3 & 5 & 7 & 6 & 1 & 4 & 0.29 \\
Elevation & 0.3 & 1 & 7 & 9 & 8 & 4 & 7 & 0.28 \\
Difference & 0.2 & 0.1 & 1 & 8 & 2 & 5 & 2 & 0.12 \\
Slope & 0.1 & 0.1 & 0.1 & 1 & 6 & 8 & 3 & 0.11 \\
Drainage & 0.2 & 0.1 & 0.5 & 0.2 & 1 & 7 & 3 & 0.08 \\
Density & 1 & 0.3 & 0.2 & 0.1 & 0.1 & 1 & 5 & 0.09 \\
Soil & 0.3 & 0.1 & 0.5 & 0.3 & 0.3 & 0.2 & 1 & 0.03 \\
Geology & & & & & & & &
\end{tabular}




\section{Figure Captions}

Figure 1. Location map of the Tana Basin. The basin located at the north of the Blue Nile River Basin; it is the source of the Blue Nile River.

Figure 2: Geological Map of the Tana basin (a. Source: BECOM, 1998) and Geology Class (b) that represents the corresponding rating of the geologic units changed in to numerical values based the aquifer media classification scheme of the DRASTIC model (Aller et al., 1987).

Figure 3: Tana basin Soil Classification (a. Source: BECOM, 1998) and the Hydrological Soil Grouping (HSG) rate (b).

Figure 4: Rainfall Stations and Areal Distribution of Precipitation in the Tana basin (a), and the Rainfall Class for overlay use (b).

Figure 5. The five class geometric distribution of the four layers developed by using the SRTM 90m DEM of the area and normalized by using Eq. 1: a) Elevation, b) Slope, c) Drainage density, and d) Topographic Index.

Figure 6. Flow chart to delineate Aquifer Potential Zones in the Tana basin and combining GRACE data with Aquifer Potential Zone of the Tana basin.

Figure 7. The Tana basin GRACE (CSR RL05) $\Delta$ TWS (cm) data with $110 \mathrm{Km}$ pixel size (a) and 90m pixel size (b). Resampling of the GRACE (CSR RL05) allows to clipping by the basins catchment divide, so the net basin $\Delta$ TWS $(\mathrm{cm})$ can be defined and the clipped product (b) is used to delineate the define hot spots of change in storage. 
Figure 8. Tana basin Distribution of the Aquifer Potential Zone Index and Potential Zone index value (left) and qualitative interpretation of the index values (right).

Figure 9. The GRACE (CSR Release-05) $\triangle$ TWS of the Tana basin (a) and the redistributed product (b) is indicated in monthly basis for the year 2006. The distribution of gain and loss sites indicate that the Poor Aquifer Potential zones are the fastest to gain and loos the $\Delta$ TWS. The very high and high Aquifer Potential zones show fluctuation of storage for extended period, however these sites remarket the largest range of change in storage fluctuation with time.

Figure 10: Net Change in Groundwater and Soil Moisture Storage of the Tana basin. Subtracting the change in Lake Level of the Lake Tana from GRACE (CSR RL05) generates the net Groundwater and Soil Moisture of the basin.

Figure 11. Inter annual storage variability (a) and the total annual net change in the groundwater and soil moisture storage (b) of the Tana basin. 